\title{
MEDIA PEMBELAJARAN BIOLOGI UNTUK SMP KELAS IX BERBASIS MULTIMEDIA
}

\author{
Lusia lamalewa, Teddy Istanto \\ Email : lusia@unmus.ac.id, teddyistanto@gmail.com \\ Jurusan Teknik Informatika, Fakultas Teknik \\ Universitas Musamus - Merauke
}

\begin{abstract}
ABSTRAK
Pelajaran Biologi merupakan ilmu yang mempelajari tentang makhluk hidup, umumnya melibatkan obyek-obyek nyata dalam kehidupan. Materi sistem ekskresi, sistem reproduksi manusia dan sistem saraf pusat merupakan materi yang dianggap abstrak, karena siswa hanya mendengar penjelasan dari guru tanpa mengetahui seperti apa sistem ekskresi dan sistem reproduksi itu. Karena tidak adanya media pembelajaran yang digunakan oleh guru di kelas, sehingga siswa tidak dapat melihat obyek dari materi pembelajaran yang dipelajari.

Aplikasi dibuat menggunakan Adobe Flash dan CMSimple bertujuan agar Guru dapat menggunakan media pembelajaran multimedia dalam menyampaikan materi, sehingga siswa dapat mengetahui obyek pembelajaran yang dipelajari, dan dapat meningkatkan pemahaman siswa tentang materi yang dipelajari.

Penggunaan aplikasi media pembelajaran biologi untuk SMP Kelas IX di kelas oleh guru biologi sebagai media alternatif dalam menyampaikan materi biologi yang membutuhkan media pembelajaran di kelas. Aplikasi yang di buat memiliki unsur multimedia, membuat siswa dapat mengetahui obyek pembelajaran yang dipelajari sehingga siswa tidak merasa bosan dan meningkatkan nilai siswa.
\end{abstract}

Kata kunci : Media Pembelajaran, Materi Biologi, Multimedia

\section{PENDAHULUAN}

Belajar adalah suatu proses yang kompleks, yang terjadi pada diri setiap orang sepanjang hidupnya. Proses belajar yang diselenggarakan secara formal di sekolah-sekolah, dimaksudkan untuk mengarahkan perubahan pada diri siswa secara terencana, baik dalam aspek pengetahuan, keterampilan, maupun sikap (Syah, 2010). Namun proses belajar mengajar yang diselenggarakan di sekolah seringkali 
siswa sulit menangkap materi yang disampaikan oleh guru. Ini dikarenakan metode pengajaran yang dilakukan oleh guru dengan memberikan ceramah kepada siswa tanpa adanya alat bantu pembelajaran yang digunakan atau media pembelajaran di kelas, sehingga mengakibatkan siswa kurang perhatian dan mempengaruhi nilai.

Pelajaran Biologi merupakan ilmu yang mempelajari tentang makhluk hidup, umumnya melibatkan obyek-obyek nyata dalam kehidupan (Syamsuri, dkk., 2006). Materi sistem ekskresi, sistem reproduksi manusia dan sistem saraf pusat merupakan materi yang dianggap abstrak, karena siswa hanya mendengar penjelasan dari guru tanpa mengetahui seperti apa sistem ekskresi dan sistem reproduksi itu. Karena tidak adanya obyek yang digunakan saat pembelajaran. Untuk membuat suatu pembelajaran yang abstrak menjadi nyata bagi siswa dibutuhkan suatu media yang sesuai dengan materi yang akan disampaikan kepada siswa. Dengan melakukan

pembaharuan pembelajaran yaitu memanfaatkan komputer sebagai media pembelajaran melalui penggunaan software pendidikan. Salah satu program software yang sedang berkembang adalah adobe flash. Adobe flash merupakan salah satu program software yang mampu menyajikan pesan audio visual secara jelas kepada siswa dan materi yang bersifat abstrak dapat diilustrasikan secara lebih menarik kepada siswa dengan berbagai gambar animasi yang dapat merangsang minat belajar siswa sehingga dapat memahami materi yang dipelajari (Hidayatullah, dkk., 2008).

Pemanfaatan multimedia
untuk pembelajaran yang
ditampilkan menggunakan Web
diharapkan dapat meningkatkan
minat belajar siswa dan juga siswa
dapat mengetahui obyek yang
dipelajari sehingga menambah
pemahaman siswa. World Wide Web
("Web") mampu menyediakan
informasi dalam berbagai media,
baik teks, gambar, animasi, maupun
kombinasinya (Yuhefizar, 2008).
Dengan memanfaatkan kemampuan


dan fungsi yang dimiliki oleh web, penelitian dikembangkan menjadi sebuah aplikasi media pembelajaran biologi untuk smp kelas ix berbasis multimedia.

\section{TINJAUAN PUSTAKA}

\section{Media Pembelajaran}

Media adalah perantara atau pengantar pesan dari pengirim kepada penerima pesan. Media apabila dipahami secara garis besar adalah manusia, materi, atau kejadian yang membangun kondisi yang membuat siswa mampu memperoleh pengetahuan, keterampilan, atau sikap. Dalam pengertian ini, guru, buku teks, dan lingkungan sekolah merupakan media. Secara lebih khusus, pengertian media dalam proses belajar mengajar cenderung diartikan sebagai alat-alat grafis, photografis, atau elektronis untuk menangkap, memproses, dan menyusun kembali informasi visual atau verbal (Arsyad, Azhar, 2010).

\section{Multimedia}

Multimedia adalah kombinasi dari komputer dan video atau multimedia secara umum merupakan kombinasi tiga elemen, yaitu suara, maka

gambar dan teks. Multimedia adalah kombinasi dari paling sedikit dua media input atau output dari data, media ini dapat audio (suara, musik), animasi, video, teks, grafik, dan gambar atau multimedia merupakan alat yang dapat menciptakan presentasi yang dinamis dan interaktif yang mengkombinasikan teks, grafik, animasi, audio, dan gambar video (Suyanto, 2004).

Unsur - unsur pendukung dalam multimedia antara lain :

1. Teks

\begin{tabular}{lr}
\multicolumn{2}{c}{ Bentuk data } \\
multimedia yang paling \\
mudah disimpan dan \\
dikendalikan adalah teks. \\
Teks merupakan yang paling \\
dekat dengan manusia dan \\
yang paling banyak dilihat. \\
Teks dapat membentuk kata, \\
surat atau narasi dalam \\
multimedia yang menyajikan \\
bahasa pengguna.
\end{tabular}

2. Grafik

Alasan untuk menggunakan gambar dalam presentasi atau publikasi multimedia adalah karena lebih menarik 


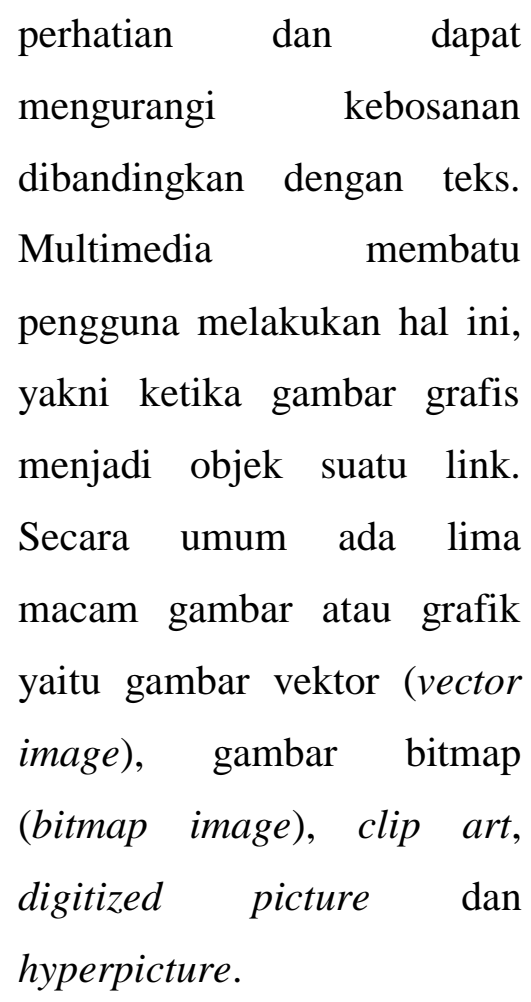

3. Suara (Sound)

Suara atau sound merupakan elemen yang paling berbeda dibanding elemen elemen multimedia lainnya. Dalam projek multimedia, suara dapat dipergunakan untuk percakapan (narasi), musik, spesial efek, background.

Beberapa jenis objek bunyi yang biasa digunakan dalam produksi multimedia yakni format waveform audio, compact disk audio, MIDI sound track dan mp3.

\section{Video}

Video adalah rekaman gambar hidup atau gambar bergerak yang saling berurutan. Terdapat dua macam video yaitu video analog dan video digital.

5. Animasi

Dalam multimedia, animasi merupakan penggunaan komputer untuk menciptakan gerak pada layar. Ada sembilan macam animasi yaitu animasi sel, animasi frame, animasi sprite, animasi lintasan, animasi spline, animasi vector, animasi karakter, animasi computational dan morphing. (Suyanto, 2004).

\section{Website}

Website adalah kumpulan dari halaman-halaman situs, yang terangkum dalam sebuah domain atau subdomain, yang tempatnya berada di dalam World Wide Web ( WWW ) di dalam Internet. Sebuah halaman web biasanya berupa dokumen yang ditulis dalam format HTML ( Hyper Text Markup Language ), yang selalu bisa diakses 
melalui HTTP, yaitu sebuah protokol yang menyampaikan informasi dari server website untuk ditampilkan kepada para pemakai melalui web browser.dan Website atau situs dapat juga diartikan sebagai kumpulan halaman yang menampilkan informasi data teks, data gambar diam atau gerak, data animasi, suara, video dan atau gabungan dari semuanya, baik yang bersifat statis maupun dinamis yang membentuk satu rangkaian bangunan yang saling terkait dimana masing-masing dihubungkan dengan jaringanjaringan halaman (hyperlink)(Yuhefizar, 2008).

\section{METODOLOGI PENELITIAN}

Metodologi yang dilakukan untuk menyelesaikan penelitian antara lain:

1. Pengumpulan data

a. Wawancara

Wawancara dilakukan terhadap guru biologi SMP kelas IX dan juga pelajar SMP, untuk mendapatkan informasi mengenai proses pembelajaran yang dilakukan dikelas dan materi Biologi yang dipelajari. b. Studi Kepustakaan

Metode ini digunakan untuk mengumpulkan teori-teori dan materi penelitian yang telah dilakukan sebelumnya tentang pembelajaran biologi SMP, dengan mencari dan mengeksplorasi pustaka baik yang berupa buku maupun filefile yang didapatkan melalui internet.

2. Analisis dan perancangan sistem Dalam tahap ini dilakukan analisis terhadap materi biologi yang akan tampilkan yaitu materi tentang Sistem ekskresi, sistem reproduksi pada manusia, dan sistem saraf pusat, kemudian merancang isi tampilan dari sistem yang akan dibuat.

Aplikasi yang dibuat diisi dengan beberapa elemen, antara lain :

a. Gambar

Gambar digunakan untuk background, keterangan dari beberapa penjelasan, dan animasi.

b. Suara

Suara digunakan untuk mengiringi tampilan, mengiringi tombol ketika 
diklik, dan lain

Aplikasi ini menggunakan

sebagainya.

animasi flash dalam tampilan

c. Teks

yang diperlukan.

Aplikasi multimedia

Gambar 1. merupakan

interaktif ini seluruhnya

flowchart (diagram alir) yang

menggunakan teks

menggambarkan urutan

bahasa Indonesia dan

langkah untuk belajar materi

juga beberapa istilah

biologi dan menyelesaikan

biologi.

latihan soal yang terdapat di

d. Animasi

dalam sistem.

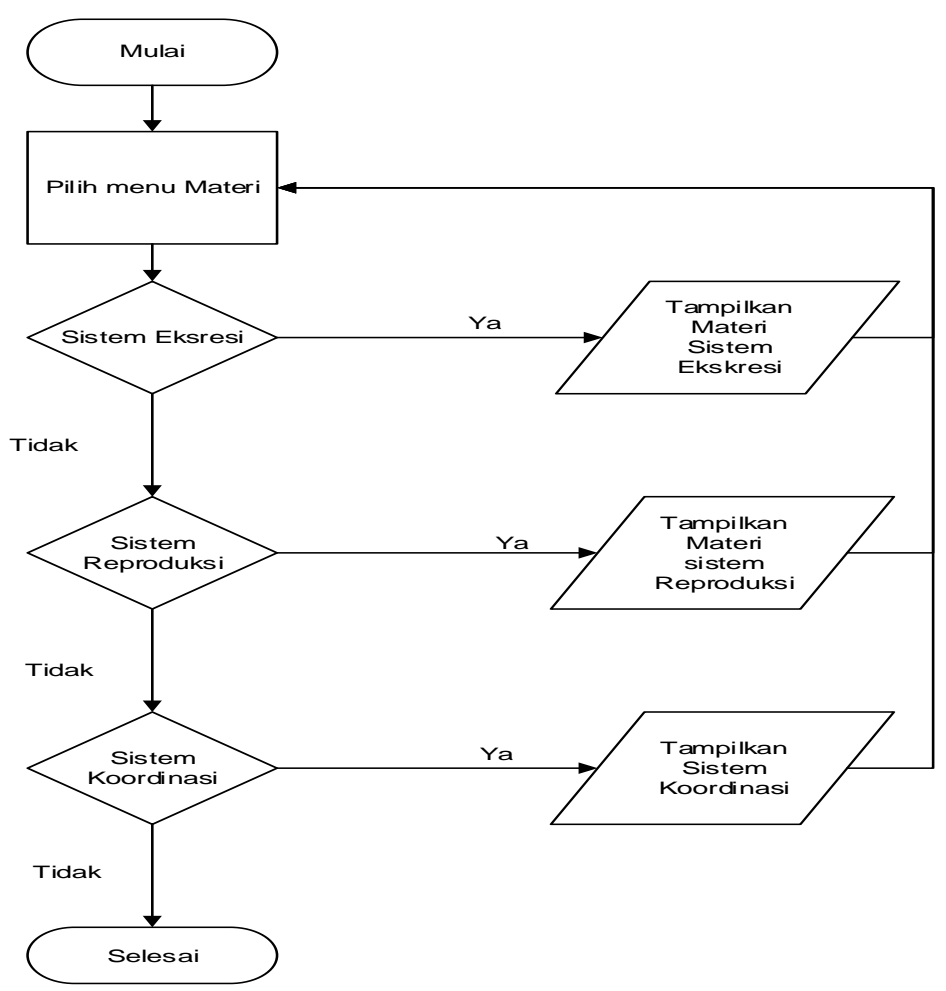

Gambar 1. Flowchart aplikasi pembelajaran biologi SMP kelas IX

3. Pembuatan Sistem

Pada tahap ini

dilakukan pembuatan perangkat

lunak sesuai dengan analisis dan

perancangan sistem yang telah ditentukan yaitu dengan menggunakan Adobe Flash dan CMSimple . Gambar 3.1 merupakan bagan atau skema yang menunjukkan alur pemilihan materi yang ada 
didalam sistem aplikasi . media pembelajaran biologi kelas IX.

\section{Pengujian}

Pengujian pengguna terhadap aplikasi yaitu: dengan membandingkan tingkat pemahaman siswa atau membandingkan nilai rata-rata kelas siswa sebelum menggunakan aplikasi multimedia dan setelah menggunakan aplikasi multimedia.

Jumlah siswa yang diuji sebelum menggunakan aplikasi dan setelah menggunakan aplikasi yaitu : Kelas F sebanyak 33 siswa dari 44 Jumlah keseluruhan siswa dan kelas G sebanyak 21 siswa dari 43 jumlah keseluruhan siswa. Dengan soal ujian sebanyak 30 soal.

\section{HASIL DAN PEMBAHASAN}

Aplikasi media pembelajaran biologi kelas IX dibuat untuk digunakan oleh pengajar guna membantu menyampaikan materi kepada siswa. Materi yang disajikan berupa ringkasan materi. Secara umum penggunaan aplikasi tidak harus oleh pengajar saja tetapi siswa pun dapat menggunakan aplikasi tanpa adanya pengajar. Aplikasi dapat digunakan siswa sebagai bahan referensi atau untuk mengulang materi dengan latihan soal yang ada pada aplikasi. Siswa didorong aktif mengolah informasi yang didapatnya dan bisa digunakan berulang-ulang sesuai keinginan. Dengan demikian, diharapkan materi dapat lebih mudah dipahami sehingga siswa mampu menerapkan teori dalam menyelesaikan soal-soal.

Sistem aplikasi media pembelajaran biologi kelas IX ini dibuat dengan bantuan tampilan teks, gambar animasi dan suara. Hal tersebut digunakan untuk membantu siswa dalam memahami materi yang diberikan.

\section{Hasil}

Dalam menjalankan aplikasi Media pembelajaran biologi untuk SMP Kelas IX, yang pertama kali tampil adalah halaman utama web, kemudian terdapat menu Home, Materi dan About serta Help.

\section{Halaman Utama}


Pada tampilan menu utama web terdapat menu Home, Materi, About, Help dan juga fungsi lain seperti Peta Situs yang berfungsi untuk melihat isi web, versi cetak untuk mencetak, Log Masuk untuk login masuk kedalam sistem untuk merubah tampilan sistem, dan Cari untuk pencarian. Pada menu Home berisikan uraian kompetensi dasar dari materi biologi yang

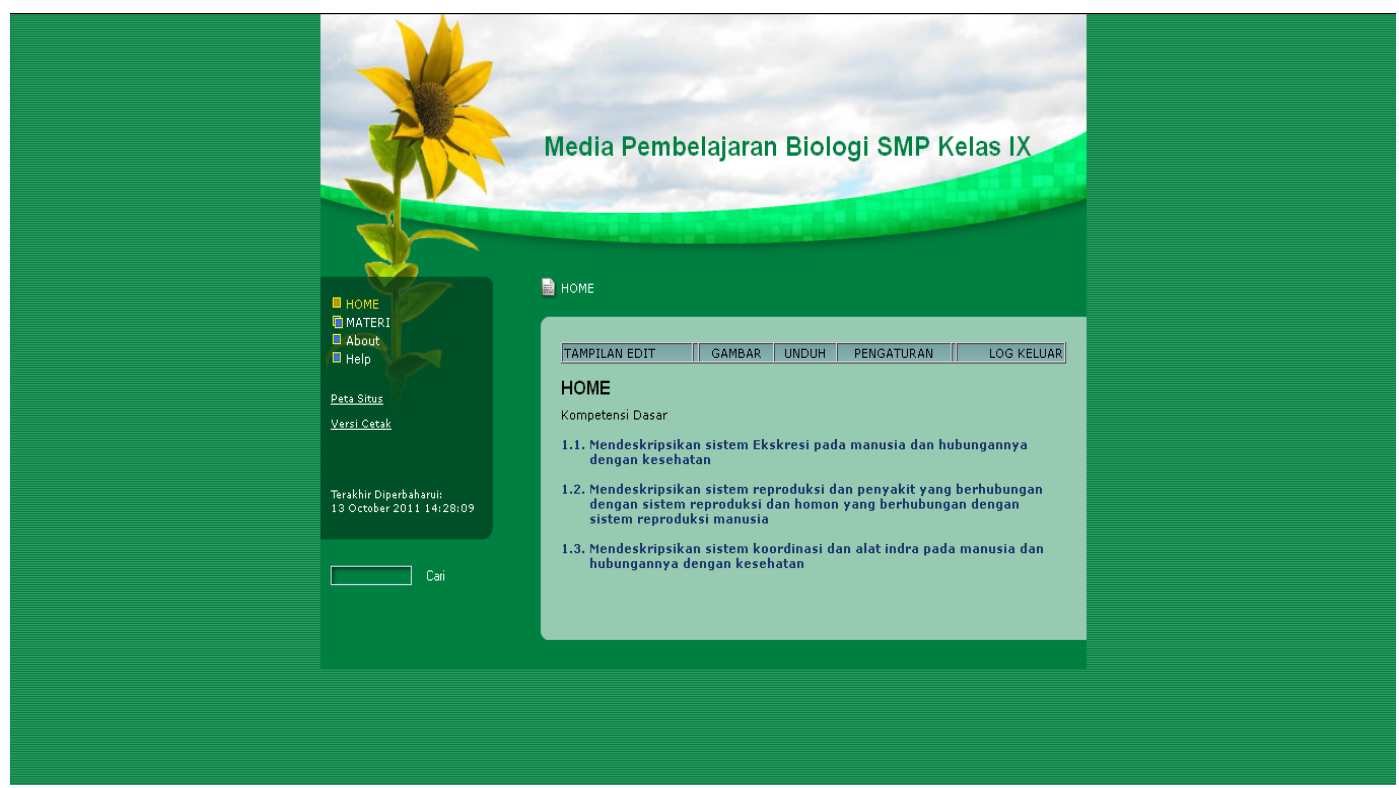

Gambar 3. Halaman Utama

\section{Tampilan Menu Materi}

Pada tampilan menu materi terdapat tiga Bab materi pelajaran Biologi yaitu Sistem Ekskresi Manusia, Sistem Reproduksi Manausia dan sistem Koordinasi dan ditampilakan, pada menu Materi berisi materi tentang sistem ekskresi manusia, sistem reproduksi manusia dan sistem koordinasi dan alat indera manusia serta terdapat tampilan Link (penghubung) yang menghubungkan antara Home dan Materi. tampilan menu utama web dapat dilihat pada Gambar 3. 


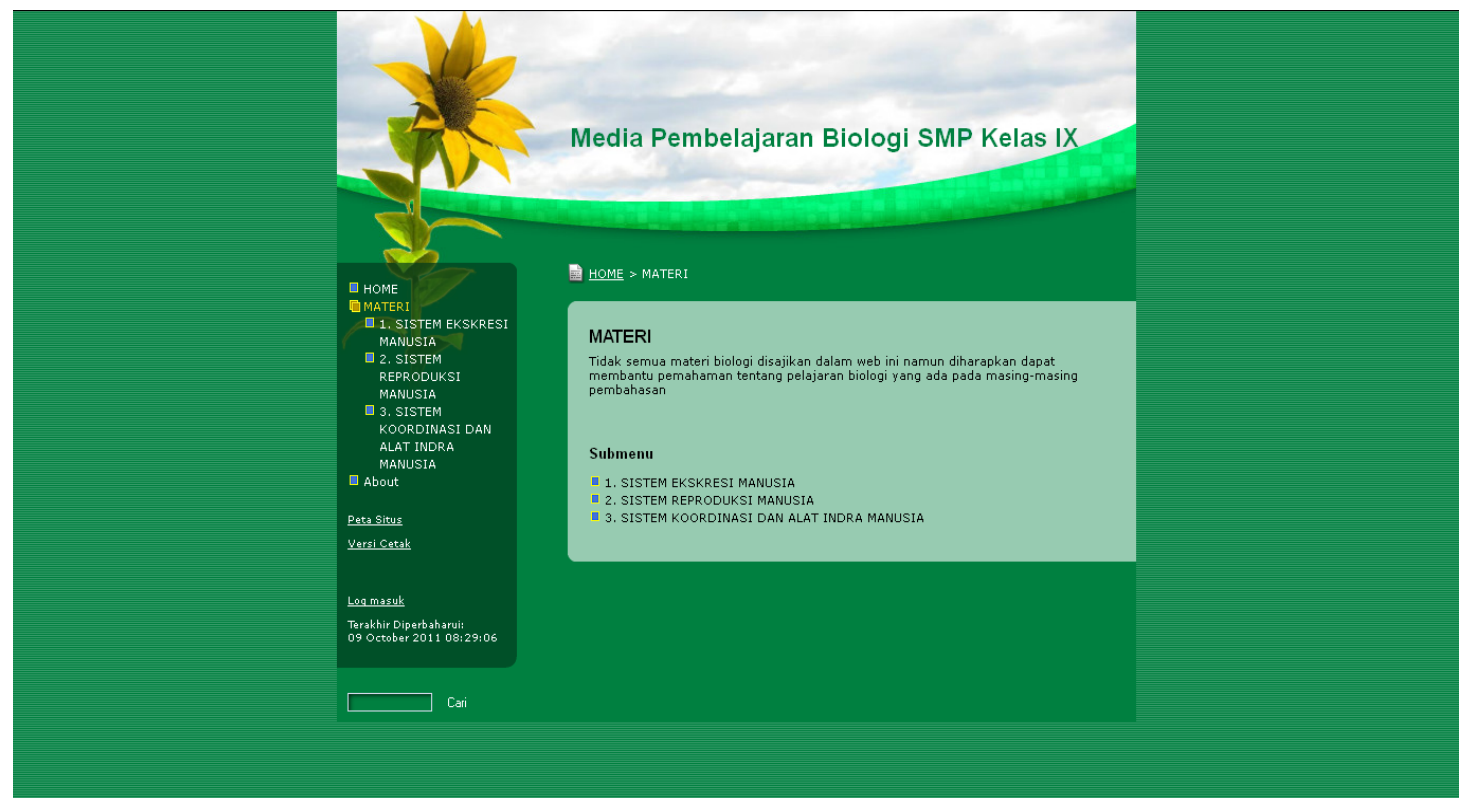

Gambar 4. Menu Materi

\section{Pembahasan}

Aplikasi media pembelajaran Biologi Untuk siswa SMP Kelas IX yang dibuat, digunakan oleh guru SMP Negeri 2 di kelas sebagai media pembelajaran dalam menyampaikan materi, sehingga siswa tidak hanya mendengar materi tetapi juga dapat melihat obyek dari pelajaran yang dipelajari.

Pengujian aplikasi dilakukan pada siswa kelas IX F dan kelas IX G SMP Negri 2 Merauke yaitu dengan melakukan simulasi di kelas. Kelas tersebut dipilih secara acak dan dilakukan pengujian terhadap materi sistem ekskresi. Jumlah siswa yang diuji sebelum menggunakan aplikasi dan setelah menggunakan aplikasi yaitu: Kelas F sebanyak 33 siswa dari 44 Jumlah keseluruhan siswa dan kelas $\mathrm{G}$ sebanyak 21 siswa dari 43 jumlah keseluruhan siswa. Dengan soal ujian sebanyak 30 soal.

Pada Tabel 1. merupakan tabel perbandingan nilai sistem ekskresi siswa sebelum menggunakan aplikasi, sesudah menggunakan aplikasi dan persentasi peningkatan nilai. 
Tabel 1. Nilai Rata-rata Kelas F dan G

\begin{tabular}{|c|c|c|c|c|}
\hline $\begin{array}{c}\text { Nama } \\
\text { Kelas }\end{array}$ & $\begin{array}{c}\text { Jumlah } \\
\text { Siswa } \\
\text { Yang di } \\
\text { uji }\end{array}$ & $\begin{array}{c}\text { Nilai Rata- rata kelas } \\
\text { sebelum } \\
\text { menggunakan } \\
\text { aplikasi }\end{array}$ & $\begin{array}{c}\text { Nilai rata-rata } \\
\text { kelas setelah } \\
\text { menggunakan } \\
\text { aplikasi }\end{array}$ & $\begin{array}{c}\text { Persentase } \\
\text { kenaikan } \\
\text { nilai siswa }\end{array}$ \\
\hline F & 33 & 75,90 & 79,60 & $4,87 \%$ \\
\hline G & 21 & 73,95 & 83,42 & $12,80 \%$ \\
\hline
\end{tabular}

Pengujian pengguna terhadap aplikasi menunjukan adanya peningkatan nilai rata - rata siswa sebelum menggunakan aplikasi dan setelah menggunakan aplikasi. Dengan persentasi kenaikan yaitu : kelas F sebanyak 4,87\% dan kelas $\mathrm{G}$ sebanyak $12,80 \%$. Dengan demikian penggunaan Aplikasi media pembelajaran biologi untuk kelas IX yang dibuat memberikan pencapaian hasil belajar yang meningkat di bandingkan dengan metode biasa.

\section{PENUTUP}

\section{Kesimpulan}

Berdasarkan hasil penelitian yang dilakukan maka diperoleh beberapa kesimpulan yaitu :

1. Penggunaan aplikasi media pembelajaran biologi untuk SMP Kelas IX berbasis multimedia di kelas oleh guru biologi SMP Negeri 2 Merauke sebagai media pembelajaran di kelas.

2. Penggunaan aplikasi Media Pembelajaran Biologi untuk SMP Kelas IX yang memiliki unsur multimedia membuat siswa dapat mengetahui obyek pembelajaran yang dipelajari sehingga siswa tidak merasa bosan dan meningkatkan nilai siswa. Dengan persentasi kenaikan yaitu : kelas F sebanyak $4,87 \%$ dan kelas $\mathrm{G}$ sebanyak $12,80 \%$.

\section{Saran}

1. Dengan adanya aplikasi media pembelajaran biologi untuk SMP Kelas IX yang dibuat di harapkan menjadi 
terobosan bagi Guru mata

pelajaran lain yang

pelajarannya

membutuhkan media

praktikum di kelas untuk

digunakannya media

pembelajaran berbasis

multimedia di kelas.

2. Untuk pengembangan selanjutnya, diharapkan aplikasi yang dibuat memiliki sebuah fungsi yang dapat menampung hasil nilai latihan dan membuat soal latihan dalam bentuk acak serta juga dapat menampilkan keseluruhan materi pelajaran Biologi dari kelas VII ,kelas VIII dan kelas IX.

\section{DAFTAR PUSTAKA}

1. Arsyad, Azhar. 2010. Media Pembelajaran. Rajawali Pers, Jakarta

2. Hidayatullah Priyanto, Amarullah Akbar, Rahim Zaky. 2008. Making Educational Animation Using Flash. Informatika, Bandung.
3. Muhibbin Syah.2010.

Psikologi Pendidikan dengan pendekatan baru. PT Remaja

Rosdakarya. Bandung

4. Wahana Komputer, Tim Peneliti dan Pengembangan. 2006. Pembuatan Animasi Dengan Macromedia Flash 8 Profesional. Penerbit Salemba Infotek, Jakarta.

5. Suyanto. 2004. Multimedia Alat untuk Meningkatkan Keunggulan Bersaing. Andi, Yogyakarta.

6. Syamsuri, Istamar, dkk. 2006. IPA BIOLOGI Jilid 3 untuk Kelas IX SMP. Penertbit Erlangga, Jakarta.

7. Syarif, Arry Maulana. 2008. 9 Manipulasi Praktis Adobe Photoshop CS, CS2 \& CS3. Elex Media Komputindo, Jakarta.

8. Yuhefizar. 2008. $10 \mathrm{Jam}$ Menguasai Internet: Teknologi dan Aplikasinya. Elex Media Komputindo, Jakarta. 